\title{
DUKUNGAN KELUARGA BERHUBUNGAN DENGAN HARGA DIRI PADA PENDERITA TUBERKULOSIS PARU
}

\author{
Ulfa Suryani*, Zulham Efendi \\ STIKES Mercubaktijaya, Jamal Jamil Pondok Kopi Siteba, Padang, Sumatera Barat, Indonesia 25173 \\ *ulfasuryani1803@gmail.com
}

\begin{abstract}
ABSTRAK
Tuberkulosis Paru menyebabkan dampak fisik dan psikologis, apabila tidak memiliki mekanisme koping dandukungan keluarga yang baik dapat menyebabkan gangguan pada harga dirinya.Tujuan dari penelitian ini untuk mengetahui hubungan dukungan keluarga dengan harga diri pada penderita Tuberkulosis Paru di Puskesmas Andalas Padang. Desain Penelitian yang digunakan adalah deskriptif korelasi dengan pendekatan secara cross sectional. Sampel penelitian diambil sebanyak 42 orang dengan cara total sampling. Pengumpulan data menggunakan kuesioner. Pada penelitian ini analisis data dilakukan secara univariat dan bivariate menggunakan uji Chi Square dengan p value $=0,05$. Hasil penelitian diketahui bahwa lebih dari separoh penderita Tuberkulosis Paru mengalami harga diri rendah $(61,9 \%)$ dengan dukungan keluarga yang kurang $(54,8 \%)$. Dengan menggunakan uji korelasi, terdapat ada hubungan yang signifikan antara dukungan keluarga dengan harga diri penderita Tuberkulosis Paru ( $\mathrm{p}$ value $=0,037$ ) memilliki nilai hubungan positif dengan interpretasi cukup.
\end{abstract}

Kata kunci: tuberkulosis paru, harga diri, dukungan keluarga

\section{FAMILY SUPPORTING RELATIONSHIPS WITH SELF-ESTEEM IN PATIENTS WITH PULMONARY TUBERCULOSIS}

\begin{abstract}
Pulmonary Tuberculosis causes physical impact and psychological sufferers, if it does not have a coping mechanism and good family supporting so it can cause the disturbance in their pride. The purpose of this research is to know about family supporting relationships with self-esteem in patients of Pulmonary Tuberculosis in PuskesmasAndalas Padang. The design of research that used is the descriptive correlations with approaching in cross sectional. The sample of research is taken as many as 42 people with using total sampling. The collecting of data uses questionnaire. In this research the analyzing of data is done by Univariat and Bivariat that uses Chi Square test with $p$ value $=0,05$. The result of research is known that more than half of patients Pulmonary Tuberculosis experience low self-esteem $(61,9 \%)$ with lack of family supporting $(54,8 \%)$. In using correlation test there is the relationship which is significant between family supporting with self-esteem of Pulmonary Tuberculosis patients $(\mathrm{p}$ value $=0,037$ ) that have a positive relationship value with enough interpretation
\end{abstract}

Keywords: pulmonary tuberculosis, self-esteem, family supporting

\section{PENDAHULUAN}

Tuberkulosis (TB) paru merupakan penyakit infeksi menular kronik yang disebabkan oleh kuman Mycobacterium tuberculosis (Jumaelah, 2011). Penyakit ini masih menjadi masalah kesehatan global menduduki urutan kedua setelah Human Imunodeficiency Virus (HIV) sebagai penyakit infeksi yang menyebabkan kematian terbanyak pada penduduk dunia (WHO, 2015). Penyakit ini dapat diderita oleh setiap orang, tetapi paling sering ditemukan pada usia muda atau usia produktif yaitu 15-50 tahun. Penyakit ini sering ditemukan pada yang bertubuh lemah, kurang gizi, atau yang tinggal satu rumah dan berdesak - desakkan bersama penderita TB Paru (Naga, 2012).

Penderita TB paru dengan pengobatan lama akan mengalami perubahan fisik dan psikologis. Perubahan dalam bentuk fisik seperti menjadi lebih kurus dan sering batuk batuk, dan pada psikologis akan menunjukkan keraguan untuk memberikan pendapat, bersikap pasif, merasa rendah diri, menarik diri dari orang lainkarena khawatir penyakitnya 
mudah ditularkan kepada orang lain (Sulistiyawati, 2012). Selain itu penderita Tuberkulosis paru akan merasa tidak berguna bagi keluarga dan masyarakat karena dapat menambah beban pikiran dalam menghadapi perubahan fisik dan psikologisnya, sehingga penderita mengalami masalah pada harga diri nya (Direja, 2011).

Harga diri adalah penilaian individu terhadap nilai personal yang diperoleh dengan menganalisis seberapa sesuai perilaku dirinya dengan ideal diri (Stuart, 2013). Pada penderita TB paru mengalami perubahan harga diri salah satunya karena saat penderita batuk dan sedang berkomunikasi dengan orang lain, penderita dapat mengalami penolakan dari lawan bicaranya, sehingga lawan bicaranya menjaga jarak saat berkomunikasi dan menimbulkan perubahan perilaku pada penderita TB paru tersebut. Perilaku pada penderita TB paru seperti : menghindari kontak mata, perawakan yang sangat kurus, penampilan tidak rapi, permintaan maaf yang berlebihan, berbicara yang ragu-ragu, terlalu kritis atau marah berlebihan, sering menangis, menilai diri negatif, ketergantungan yang berlebihan, raguragu untuk menunjukkan pandangan atau pendapat, kurang berrminat pada apa yang terjadi, bersikap pasif dan kesulitan dalam membuat keputusan (Potter\&Perry, 2010).

Menurut hasil penelitian yang dilakukan oleh Dedeh (2016) tentang gambaran harga diri penderita Tuberkulosis paru di Wilayah Eks Kawedanan Indramayu didapatkan bahwa responden yang memiliki harga diri tinggi sebanyak $51,1 \%$ dan responden yang memiliki harga diri rendah sebanyak $48,9 \%$.Sedangkan menurut hasil penelitian yang dilakukan oleh Yastriana (2013) tentang gambaran harga diri pada pasienTuberkulosis di Poliklinik Paru RS Persahabatan didapatkan bahwa responden yang memiliki harga diri tinggi sebanyak $89,9 \%$ dan responden yang memiliki harga diri rendah sebanyak $10,1 \%$.

Penderita Tuberkulosis paru dapat mengakibatkan penurunan daya tahan tubuh dan kelemahan fisik, sehingga mengakibatkan keterbatasan dalam melaksanakan aktivitas harian yang akan berdampak pada pendapatan nya dalam segi ekonomi. Selain itu juga memberikan dampak dalam kehidupan sosial, memunculkan stigma bahkan dapat mengakibatkan isolasi sosial. Keadaan tersebut dapat mempengaruhi harga diri penderita TB paru (Depkes, 2009). Menurut Sulistiyawati (2012), mengatakan bahwa responden dengan harga diri tinggi (normal) disebabkan karena adanya mekanisme koping yang baik. Untuk meningkatkan harga diri penderita TB paru, keluarga dapat memberikan motivasi kepada penderita TB paru agar harga diri nya dapat meningkat (Nuha, 2013).

Faktor-faktor yang berhubungan dengan harga diri antara lain meliputi : penolakan orang tua, kegagalan yang berulang kali, kurang mempunyai tanggung jawab personal, ketergantungan pada orang lain dan ideal diri yang tidak realistis (Dariuszky, 2009). Dalam mengahadapi hal tersebut penderita tuberkulosis sangatlah membutuhkan dukungan keluarga dalam kesembuhan yang berupa memberikan sarana prasarana, menyediakan dana pengobatan, meluangkan waktu untuk mendampingi berobat dan saat dirumah maupun bergaul dilingkungan sekitarnya (Nuha, 2013). Dukungan sosial yang memberikan dampak terbesar adalah dukungan yang diberikan oleh keluarga (Makhfudli, 2009).

Menurut penelitian yang dilakukan oleh Abdullah (2015) tentang hubungan dukungan keluarga pasien rawat inap Tuberkulosis paru di RS Paru Jember yaitu, responden yang mendapatkan dukungan keluarga baik sebanyak 56,8\%, dukungan keluarga cukup sebanyak $34,1 \%$, dan dukungan keluarga kurang sebanyak $9,1 \%$. Sedangkan menurut penelitian Ulfah (2013) juga menunjukan hubungan dukungan keluarga dengan pasien TB paru yaitu, pada dukungan keluarga kurang sebanyak $47,1 \%$ responden dan dukungan keluarga baik sebanyak 52,9\%. Dari penelitian tersebut didapatkan hubungan yang signifikan antara dukungan keluarga dengan harga diri pasien TB paru yang mempunyai hubungan yang positif, yang artinya semakin baik dukungan keluarga semakin tinggi pula harga diri pada pasien Tuberkulosis paru tersebut.

Berdasarkan survei awal yang dilakukan peneliti pada tanggal 2 Oktober 2019 di Puskesmas Andalas Padang terhadap 10 orang responden, ditemukan 6 orang responden mengungkapkan minder, tidak nyaman ditanya tentang penyakitnya, dan jaga jarak karena 
khawatir penyakit ini dapat menular, mengungkapkan malu karena minum obat selama 6 (enam) bulan berturut-turut, ketika berobat hanya sendirian, dan keluarganya jarang memberikan informasi tentang penyakitnya. Sedangkan 4 orang responden ketika diajak untuk berkomunikasi mengatakan bahwa penyakitnya ini bisa sembuh, tidak merasa malu dan responden juga mengungkapkan keluarganya sering mengingatkan Berdasarkan latar belakang masalah tersebut, maka peneliti tertarik untuk melakukan penelitian tentang "Hubungan Dukungan Keluarga Terhadap Harga diri Pada Penderita Tuberkulosis Paru di Puskesmas Andalas Padang Tahun 2019”.
METODE

Jenis penelitian yang digunakan adalah deskriptif korelasi dengan pendekatan secara cross sectional, ). Populasi dalam penelitian ini adalah penderita TB paru yang berkunjung di Puskesmas Andalas Padang Tahun 2019. Populasi penderita TB Paru di Puskesmas Andalas sebanyak 42 orang. Penelitian ini menggunakan teknik pengambilan sampel total sampling yaitu 42 orang, penentuan sampel dengan cara mengambil seluruh anggota populasi sebagai responden atau sampel (Sugiyono, 2013).

\section{HASIL}

Hasil penelitian dapat dilihat pada tabel berikut.

Tabel 1.

Dukungan keluarga pada penderita TB Paru $(n=42)$

\begin{tabular}{ccc}
\hline Dukungan Keluarga & f & $\%$ \\
\hline Kurang & 23 & 54,8 \\
Baik & 19 & 45,2
\end{tabular}

Tabel 1 terlihat bahwa lebih dari separoh $(54,8 \%)$ responden mengalami dukungan keluarga kurang.

Tabel 2.

Harga Diri Pada Penderita TB Paru $(n=42)$

\begin{tabular}{ccc}
\hline Harga Diri & f & \% \\
\hline Rendah & 26 & 61,9 \\
Tinggi & 16 & 38,1
\end{tabular}

Tabel 2 terlihat bahwa lebih dari separoh $(61,9 \%)$ responden mengalami harga diri rendah.

Tabel 3.

Hubungan dukungan keluarga dengan harga diri pada penderita TB Paru $(n=42)$

\begin{tabular}{|c|c|c|c|c|c|c|c|}
\hline \multirow{3}{*}{$\begin{array}{c}\text { Dukungan } \\
\text { Keluarga }\end{array}$} & \multicolumn{4}{|c|}{ Harga Diri } & \multirow[t]{3}{*}{ Total } & \multirow[t]{3}{*}{$\%$} & \multirow{3}{*}{$\begin{array}{c}P \\
\text { value }\end{array}$} \\
\hline & \multicolumn{2}{|c|}{ Tinggi } & \multicolumn{2}{|c|}{ Rendah } & & & \\
\hline & f & $\%$ & $\mathrm{f}$ & $\%$ & & & \\
\hline Kurang & 5 & 11,9 & 18 & 42,9 & 23 & 54,8 & \\
\hline Baik & 11 & 26,2 & 8 & 19,0 & 19 & 45,2 & 0,037 \\
\hline
\end{tabular}

Berdasarkan tabel 3terlihat bahwa dari proporsi harga diri rendah lebih banyak ditemukan pada dukungan keluarga kurang $(42,9 \%)$ dari pada dukungan keluarga baik $(19,0 \%)$, begitu sebaliknya responden dengan harga diri tinggi lebih banyak ditemukan pada dukungan keluarga baik $(26,2 \%)$ dibandingkan dukungan keluarga kurang (11,9\%). Berdasarkan uji statistik menggunakan uji chi Square terlihat nilaip $=0,037(\mathrm{p}<0,05)$.

\section{PEMBAHASAN}

\section{DukunganKeluarga}

Berdasarkan analisa hasil penelitian tentang dukungan keluarga terhadap 42 reponden penderita tuberkulosis paru di Puskesmas Andalas Padang, didapatkan bahwa lebih dari separoh $(54,8 \%)$ responden mendapatkan dukungan keluarga yang kurang.

Hasil penelitian tersebut sesuai dengan penelitian Safrida (2011) tentang dukungan keluarga terhadap penderita TB Paru di RSUD 
Sidikalang, ditemukan bahwa 36 orang $(40,7 \%)$ responden mempunyai dukungan keluarga yang kurang. Hasil penelitian tersebut juga sesuai dengan penelitian Muhardiani (2015) di Wilayah kerja Puskesmas Gang Sehat yang mengalami dukungan keluarga kurang sebanyak 41 orang $(52,6 \%)$. Sedangkan hasil penelitian ini berbeda dengan hasil penelitian yang dilakukan oleh Lilis (2008), dimana hasil penelitiannya menunjukan bahwa sebagian besar responden 47 orang (87\%) mendapat dukungan keluarga yang baik.

Dukungan keluarga adalah suatu bentuk hubungan interpersonal yang meliputi sikap, tindakan penerimaan terhadap anggota keluarga, sehingga anggota keluarga merasa ada yang memperhatikan. Dukungan keluarga adalah sikap, tindakan penerimaan keluarga terhadap anggota keluarganya, berupa dukungan informasional, dukungan penilaian, dukungan instrumental dan dukungan emosional (Friedman, 2010).

Dukungan keluarga kurang disebabkan karena keluarga sering acuh tak acuh terhadap penderita TB Paru, keluarga tidak pernah memberikan nasehat dan motivasi untuk berusaha melawan penyakit TB paru, keluarga selalu memberikan respon yang negatif terhadap keluhan penyakit tersebut, keluarga tidak pernah menyediakan waktu serta fasilitas yang dibutuhkan penderita tuberkulosis paru, keluarga tidak pernah menyediakan makanan bergizi seperti sayur, daging, dan telur untuk membantu penyembuhan penderita TB paru dan keluarga tidak pernah mengingatkan informasi tentang pentingnya minum obat dengan teratur.

Penderita tuberkulosis paru perlu mendapatkan dukungan keluarga baik, karena dukungan dari orang-orang secara langsung dapat menurunkan beban psikologis sehubungan dengan penyakit yang dideritanya. Disamping itu keluarga sebagai tempat yang aman dan damai untuk menenangkan pikiran, dan setiap orang pasti membutuhkan bantuan dari keluarga. Dukungan dan perhatian dari keluarga merupakan bentuk penghargaan positif yang diberikan kepada individu. Disamping itu, dukungan keluarga juga memegang peran penting dalam kehidupan penderita tuberkulosis paru berjuang untuk mencapai kesembuhan, berfikir kedepan dan menjadikan hidupnya lebih berkualitas.

\section{Harga Diri Penderita TB Paru}

Berdasarkan hasil analisa penelitian tentang harga diri terhadap 42 responden penderita tuberkulosis paru di Puskesmas Andalas Padang, didapatkan bahwa lebih dari separoh $(61,9 \%)$ responden mengalami harga diri yang rendah. Hasil penelitian di atas sesuai dengan penelitian Ayu (2014) terhadap harga diri penderita TB paru di wilayah kerja Puskesmas bendosari harga diri rendah sebanyak 18 orang $(52,9 \%)$, dan dengan penelitian Yuliana (2014) pada penderita TB paru di RSUD Arifin Achmad pekanbaru bahwa rata-rata responden memiliki harga diri rendah sebanyak 26 orang $(63,7 \%)$, dan sesuai dengan penelitian Safrida (2011) tentang harga diri pasien TB Paru yang dirawat di RSUD Sidikalang sebanyak 54 orang $(61,4 \%)$ yang mengalami harga diri rendah.

Menurut Dalami (2009), harga diri adalah penilaian individu tentang pencapaian diri dengan menganalisa seberapa jauh perilaku sesuai dengan ideal diri.Harga diri rendah yaitu perasaan yang negatif terhadap diri sendiri, termasuk hilangnya percaya diri dan harga diri, merasa gagal mencapai keinginan, mengkritik diri sendiri, penurunan produktivitas, perasaan tidak mampu, dan menarik diri secara sosial (Stuart, 2009). Beberapa pandangan ahli menjelaskan bahwa keberhasilan dalam penyembuhan dari pasien sangat tergantung dari harga diri yang tidak terganggu. Seseorang yang menderita penyakit kronis seperti TB paru akan mempengaruhi harga diri penderita baik secara langsung maupun tidak langsung. Semakin banyak penyakit kronis yang mengganggu kemampuan beraktivitas dan mempengaruhi keberhasilan seseorang, maka akan semakin mempengaruhi harga diri rendah (Potter\&Perry. 2010).

Neill (2011) menambahkan haga diri rendah merupakan gejala awal yang mendahului penyakit, reaksi ansietas, ketidaknyamanan dan banyak keadaan lainnya. Pendapat tersebut sesuai dengan laporan hasil penelitian ini. Hal ini ditunjukkan dari kondisi pasien dengan penyakit kronis yakni TB paru yang sudah mengetahui tentang penyakitnya. Harga diri rendah penderita tuberkulosis paru disebabkan oleh penolakan dari lingkungannya, dimana 
penderita tuberkulosis batuk terus menerus mengakibatkan penderita sulit bergaul di lingkungan masyarakat, merasa minder karena kurang percaya diri dengan penyakit tuberkulosis serta merasa tidak dihargai dan disisihkan oleh orang lain.

Selain itu penderita TB paru mengalami harga diri rendah disebabkan karena pasrah dalam segala hal yang menyatakan bahwa penyakit yang dideritanya tersebut adalah cobaan yang diberikan Tuhan, dan penderita TB Paru tersebut mengekpresikan rasa malu terhadap penyakit yang dideritanya serta menimbulkan rasa tidak yakin bisa sembuh. Disamping itu penderita TB Paru dengan harga diri rendah sering merasa tidak berdaya, menolak, merasa bersalah, merasa rendah diri, dan menarik diri dari orang lain karena khawatir penyakit yang diderita menular kepada orang lain.

\section{Hubungan Dukungan Keluarga Dengan Harga Diri Pada Penderita TB Paru}

Hasil Penelitian dapat dilihat bahwa proporsi harga diri rendah lebih banyak ditemukan pada dukungan keluarga kurang $(42,9 \%)$ dari pada dukungan keluarga baik $(19,0 \%)$, begitu sebaliknya responden dengan harga diri tinggi lebih banyak ditemukan pada dukungan keluarga baik (26,2\%) dibandingkan dukungan keluarga kurang (11,9\%). Berdasarkan uji statistik menggunakan uji chi Square terlihat nilaip $=0,037(\mathrm{p}<0,05)$.

Kuntjoro (2011) mengatakan bahwa dukungan keluarga sebagai suatu komponen penting yang diberikan ketika penderita menghadapi masalah kesehatan yang membutuhkan suatu penanganan yang serius. Melalui dukungan keluarga tersebut penderita merasa diperhatikan dan dihargai sehingga dapat memotivasi penderita untuk mengikuti pengobatannya. Beberapa kajian ilmiah lain menjelaskan bahwa keluarga memainkan suatu peran yang bersifat mendukung selama dalam proses peningkatan harga diri pada penderita sehingga dapat tercapai tingkat kesehatan yang optimal. dukungan keluarga yang natural dan alami diterima oleh seseorang melalui interaksi sosial dalam kehidupannya secara spontan dengan orang-orang terdekat yang ada disekitarnya. Hal ini terkait dengan hubungan interpersonal yang buruk, dan gangguan harga diri dapat digambarkan sebagai perasaan negatif terhadap diri sendiri termasuk hilangnya percaya diri (Christeen, 2009).

Coleman dalam Djiwatampu (2009), yang menjelaskan bahwa harga diri rendah adalah sebab dari dasar dari beberapa penyakit, tetapi sebenarnya bukan harga diri rendah yang membunuh atau melukai orang tetapi cara seseorang menghadapi harga dirinya tersebut. Penderita tuberkulosis paru yang mengalami harga diri rendah disebabkan karena harga diri rendah dapat terjadi secara situasional (trauma) atau kronis terhadap dirinya sendiri meskipun dukungan keluarga baik telah diberikan. Sebagian besar harga diri rendah disebabkan karena penderita TB Paru merasa tidak bisa memiliki kesempatan lagi untuk bergabung ataupun berinteraksi dengan orang lain lagi dan selalu merasa disisihkan dari orang lain. Sehingga pencapaian kesembuhan dari penyakit yang dideritanya selalu gagal dan berulang-ulang kembali untuk berobat tetapi tidak mencapai hasil yang maksimal sehingga cenderung harga diri penderita TB Paru tersebut rendah.

\section{SIMPULAN}

Hasil penelitian menunjukkan bahwa adanya hubungan dukungan keluarga dengan harga diri pada penderita TB paru di Puskesmas Andalas Padang Tahun 2019. penelitian ini sebagai masukkan untuk memperhatikan jika dukungan dan motivasi keluarga adalah hal yang penting untuk menunjang agar harga diri penderita TB Paru dapat meningkat.

\section{DAFTAR PUSTAKA}

Ali, Z. 2009. Pengantar Keperawatan Keluarga. Jakarta : EGC

Dalami, Ermawati. dkk. 2009. Asuhan Keperawatan Klien Dengan Gangguan Jiwa. Jakarta : Trans Info Media

Friedman, M. 2010. Keperawatan Keluarga: Teori dan Praktek, Edisi 3. Jakarta : EGC

Girsang, Yastriana. L. 2013. Gambaran Harga Diri Pasien Tuberkulosis Di Poliklinik Paru Persahabatan. Sumatera Selatan : Universitas Indonesia 
Hafidz, Abdullah. dkk. 2015. Hubungan Dukungan Keluarga Dengan Harga Diri Pasien Rawat Inap Tuberkulosis Paru Di RS Jember. Jember : Universitas Muhammadiyah Jember. Diambil dari: http://www.umj-1x-abdullahha-3266-1artik.pdf Diakses 20 Oktober 2019

Keliat, B. A., \& Akemat. 2009. Model praktik keperawatan profesional jiwa. Jakarta: EGC.

Manurung, Santa, dkk. 2008. Asuhan Keperawatan Gangguan Sistem Pernafasan Akibat Infeksi. Jakarta : Trans Info Media

Notoadmodjo, S. 2010. Metodologi Penelitian Kesehatan. Jakarta: Rineka Cipta.

Nursalam. 2013. Konsep dan Penerapan Metodologi Penelitian Ilmu Keperawatan. Jakarta :SalembaMedika.

Potter, P. A. \& Perry, A. G. 2010.Fundamental Keperawatan :Konsep, Proses, danPraktik. Volume 1.Edisi 4.Jakarta : EGC.

Saragih, Safrida. W. 2011. Hubungan Dukungan Keluarga Dengan Harga Diri Pasien TB Paru Yang Dirawat di Rumah Sakit Umum Daerah Sidikalang. Sumatera Utara : Universitas Sumatera Utara.: http://www.123dok.HubunganDukungan Keluarga.pdfDiakes 20 Desember 2017
Smeltzer, S.C, Bare, B.G, J.L, \& Cheever, K.H. 2010.Buku Ajar KeperawatanMedikalBedah Brunner \&Suddarth's.Jakarta : EGC.

Sudiharto.2007. Asuhan Keperawatan Keluarga Dengan Pendekatan Keperawatan Transkultural.Jakarta : EGC

Sugiyono. 2010. Metode Penelitian Kuantitatif, Kualitatif dan R \& D, CV. Bandung : Alfabeta.

Sulistiyawati, \& Kurniawati. 2012. Hubungan Dukungan Keluarga Dengan Tingkat Stressor Pada Pasien Tuberculosis Usia Produktip di RSU Muhammadiyah Yogyakarta. Diambil dari : http://jurnal.dikti.go.id/. Diakses tanggal 10 Deesember 2019

Stuart \& Sundeen. 2013. Buku Saku Keperawatan Jiwa. Jakarta : EGC

Somantri, Irman. 2013. Askep PadSa Pasien Dengan Gangguan Sistem Pernafasan. Jakarta :SalembaMedika.

Sugiyono. 2010. Metode Penelitian Kuantitatif, Kualitatif dan R \& D, CV. Bandung :Alfabeta.

Suhron, M. 2017. Terapi Dan Askep Konsep Diri. Jakarta : Mitra Wacana Media 